\title{
DIFFERENCE AND DISABILITY IN THE MEDIEVAL ISLAMIC WORLD
}





\section{DIFFERENCE AND DISABILITY IN THE MEDIEVAL ISLAMIC WORLD}

BLIGHTED BODIES

$\infty$

Kristina L. Richardson

EDINBURGH

University Press 
This book is dedicated to Wednesday, 9 May 2007

(C) Kristina L. Richardson, 2012

Edinburgh University Press Ltd

22 George Square, Edinburgh EH8 9LF

www.euppublishing.com

Typeset in 11/13 JaghbUni Regular by

Servis Filmsetting Ltd, Stockport, Cheshire, and

printed and bound in Great Britain by

CPI Group (UK) Ltd, Croydon CR0 4YY

A CIP record for this book is available from the British Library

ISBN 9780748645077 (hardback)

ISBN 9780748645084 (webready PDF)

ISBN 9780748664917 (epub)

ISBN 9780748664900 (Amazon ebook)

The right of Kristina L. Richardson to be identified as author of this work has been asserted in accordance with the Copyright, Designs and Patents Act 1988. 